\title{
Ahlâk ve Siyasetin Belirleyici İlkesi Olarak Adâlet: Mâverdî Merkezli Okuma
}

\author{
Fatih Aydin \\ Dr., Düzce Üniversitesi (ROR ID: 04175wc52) \\ İlahiyat Fakültesi, İslam Felsefesi Anabilim Dalı \\ Dr., Duzce University Faculty of Theology, Departmant of Islamic Philosophy \\ Düzce/Turkey \\ fatihaydin@duzce.edu.tr \\ ORCID: 0000-0003-0672-5822

\section{Justice as the Determining Principle of Morality and Politics: al-Māwardī Based Reading}

\begin{abstract}
In this article, it is aimed to examine the understanding of justice in the context of al-Māwardì's moral and political thought. In the tradition of Islamic thought, although justice is generally examined with its philosophical / theoretical content, the works written on its application in practical life are limited. In this study, we will trace al-Māwardì's approach to how justice should be applied in practical life, from ethics to politics and state administration, based on his own works. In al-Māwardì's thought, ethics and politics that united in the virtue of justice, are considered as two basic fields that complement each other. Besides being a virtue in itself, justice as a moral concept is the main virtue from which the virtues originate. He emphasizes that the person must first be just to himself by establishing a relationship between the justice and moderate. This is possible if a person stands in moderate between excess and deficiency/inadequacy, directs oneself to the good and the right, and prevents oneself from bad deeds. Since justice is the preference of the balanced in one's behavior, a person who cannot show good and right behaviors torment himself. al-Māwardī's discusses the justice under two headings as justice against into oneself and others. Being, being on the right path, avoiding nasty things and not exceeding the limits in his behavior, etc. can be listed as justice to oneself. Justice towards others means that people act in a balanced way in accordance with social life/etiquette. The fairness of the administrator in approaching his/her citizens is also considered within this scope. Because in politics, justice is the basic principle that determines the principles that regulate the individual-individual, individual-state, stateindividual relationship. Justice that the indispensable principle of living together has many aspects such as from the words and actions of the individual to the rule of law and income distribution. Recognizing the need for morality in politics, al-Māwardī aimed to establish an effective and realistic administration theory based on moral principles in politics, and therefore urge the justice as the first principle of state administration. In this respect, justice is regarded as a basic principle that determines the rules of the relationship between the ruler and the ruled, as a fundamental
\end{abstract}

Intihal Taraması/Plagiarism Detection: Bu makale intihal taramasından geçirildi/This paper was checked for plagiarism Geliş/Received: 04 Temmuz/July 2020 |Kabul/Accepted: 25 Ağustos/August 2020|Yayın/Published: 20 Eylül/September 2020 Atıf/Cite as: Fatih Aydın, "Ahlâk ve Siyasetin Belirleyici İlkesi Olarak Adâlet: Mâverdî Merkezli Okuma = Justice as the Determining Principle of Morality and Politics: al-Māwardī Based Reading”, Eskiyeni 42 (Eylül/September 2020), 1077-1094. https://doi.org/10.37697/eskiyeni.764037

Copyright @ Anadolu İlahiyat Akademisi/Anatolian Theological Academy, 06050, Ankara, Turkey | www.anilakademi.com CC BY-NC 4.0 | This paper is licensed under a Creative Commons Attribution-NonCommercial License 
duty of the state, as well as being a moral virtue. al-Māwardī emphasized the comprehensive justice principle in order the justice encompass the entire society within the framework of the rule of law. He also acknowledge the justice as a balancing factor for the power and legitimacy of power. According to him, justice that encompasses everyone is an important principle that ensures order and unity in society. Thanks to the comprehensive justice, the people's commitment to the administration increases, the country becomes prosperous, so the administrator can be safe. In this way, justice becomes a tool that ensures the legitimacy of the actions of political administration. alMāwardī, who sees justice as the balancing factor of the power, associates the ideal practice of justice with religious values and the qualities of the ruler.

In order for the state administration to function in a healthy and purposeful way, al-Māwardī emphasizes principles rather than institutions, and he states that the state organs that will exercise justice should not give up the principles on the distribution of justice. The administrator should act on the principle of equality by starting with himself, and then pay attention to the appointment of judges who will execute the distribution of justice and to speed up the trial. Likewise, al-Māwardī sees justice as a principle limiting the powers of the ruler. In this respect, justice is an important balancing factor that determines the limits of the ruler's approach to his people and ensures the legitimacy of the government. This approach of Mâverdî has been considered valuable by some political philosophers since it aims to establish an authority based on rights and justice instead of authority based on power. As a result, it seems that according to Mâverdî, who emphasizes justice everywhere in his works, justice is a unchanging fundamental virtue in every field from individual life to state administration.

\section{Keywords}

Moral, al-Māwardī, Justice, State Administration, Virtue

\section{Ahlâk ve Siyasetin Belirleyici İlkesi Olarak Adâlet: Mâverdî Merkezli Okuma}

\section{Öz}

Bu makalede Mâverdînnin ahlâk ve siyaset düşüncesi bağlamında adâlet anlayışının irdelenmesi hedeflenmektedir. İslam düşünce geleneğinde adâlet, genellikle felsefi/teorik içeriğiyle değerlendirilmekle birlikte pratik hayatta uygulanış şekline dair kaleme alınan eserler sayıca azdır. Bu çalışmada Mâverdî̉nin kendi eserlerinden hareketle onun ahlâktan siyasete, devlet yönetimine kadar adâletin pratik hayatta nasıl uygulanması gerektiğine dair yaklaşımının izlerini süreceğiz. Mâverdînnin düşünce dünyasında adalet erdemi paydasında birleșen ahlâk ve siyaset, birbirini tamamlayan iki temel alan olarak kabul edilir. Bir ahlâk kavramı olarak adâlet başılı başına bir erdem olmasının yanında erdemlerin kendisinden çıktı̆̆ı ana erdemdir. Mâverdî adalet ile itidal (denge) arasında ilişki kurmak suretiyle kişinin öncelikle kendine karşı adaletli olması gerektiğini vurgular. Bu ise kişinin aşırılık ile eksiklik/yetersizlik arasında dengede durması, kendisini iyi ve güzel olana yönlendirmesi, kötülüklerden alıkoymasıyla mümkündür. İnsanın davranışlarında dengeli olanı tercih etmesi adâlet olduğundan dolayı kendinde iyi ve güzel davranışları gösteremeyen kimse kendine zulmetmiş olur.

Mâverdî adâleti kişinin kendisine ve başkasına olmak üzere ikiye ayırır. Kişinin kendisine karşı adâleti doğru yolda olması, çirkin şeylerden uzak durması ve davranışlarında sınırı aşmaması vb. sıralanabilir. Başkalarına karşı adâlet ise insanların sosyal yaşam/görgü kurallarına uygun dengeli davranması anlamına gelir. Yöneticinin vatandaşlarına karşı yaklaşımında adaletli olması da bu kapsamda değerlendirilir. Zira siyasette adâlet birey-birey, birey-devlet, devlet-birey ilişkisini düzenleyici esasları belirleyen temel ilkedir. Bir arada yaşamanın vazgeçilmez ilkesi adâletin bireyin 
söz ve eylemlerinden hukukun üstünlüğü ve gelir dağllımı gibi hususlara kadar pek çok yönü vardir.

Siyasetin ahlâka duyduğu ihtiyacı fark eden Mâverdî, siyasette ahlâkî ilkelere dayanan etkili ve gerçekçi bir yönetim teorisi kurmayı hedeflemiş; bunun için adâleti devlet yönetiminin en birinci ilkesi olarak görmüștür. Bu yönüyle adâlet ahlâkî bir erdem olmasının yanında devletin temel bir görevi olarak yöneten-yönetilen arasındaki ilişkinin kuralları belirleyen temel bir ilke olarak görülür. Mâverdî, adâletin hukuk devleti çerçevesinde toplumun tamamını kuşatması için kapsamlı adâlet ilkesine vurgu yapmıştır. Ayrıca o, adâleti iktidarın gücü ve meşruiyeti için dengeleyici bir unsur olarak görür. Ona göre herkesi kuşatan adâlet toplumda düzenin ve birliğin tesisini sağlayan önemli bir ilkedir. Kapsamlı adâlet sayesinde halkın yönetime bağlılığı artar, ülke bayındır hale gelir, böylelikle yönetici güven içinde olur. Bu şekilde adâlet siyasal yönetimin icraatlarının meşruluğunu temin eden bir araç haline gelir. Adâleti iktidarın gücünü dengeleyici unsur olarak gören Mâverdî yönetimde adâletin ideal uygulamasını dinî değerlerle ve yöneticinin sahip olduğu niteliklerle ilişkilendirir.

Devlet yönetiminin sağlıklı ve amaca uygun bir şekilde işleyebilmesi için kurumlardan ziyade ilkelere önem veren Mâverdî adâleti icra edecek devlet organlarının adâletin dağıtımı konusunda ilkelerden vazgeçmemesi gerektiğini belirtir. Yönetici kendisinden başlamak üzere eşitlik ilkesine göre hareket etmeli, adâletin dağıtımını icra edecek kadıların tayinine ve yargılamanın hızlandırılmasına dikkat etmelidir. Aynı şekilde Mâverdî, adâleti yöneticinin yetkilerini sınırlayan bir ilke olarak görür. Bu yönüyle adâlet yöneticinin halkına yaklaşımının sınırlarını belirleyen dengeleyici ve iktidarın meşruiyetini sağlayıcı önemli bir unsurdur. Mâverdî̀nin bu yaklaşımı kimi siyaset filozofları tarafından üretilen güce dayalı otorite yerine hakka dayalı bir otorite tesis etmeyi hedeflediğinden dolayı değerlidir. Sonuç olarak eserlerin her yerine adâlet vurgusunun nakședilmiş olduğunu gördüğümüz Mâverdînin metinlerinde adâletin bireysel hayattan devlet idaresine kadar her alanda anahtar niteliğinde değişmeyen temel bir erdem olduğunu anlamamız mümkündür.

\section{Anahtar Kelimeler}

Ahlâk, Mâverdî, Adâlet, Devlet Yönetimi, Erdem

\section{Giriş}

Adâlet insanlık tarihi boyunca bütün semavî dinlerin ve düşünce geleneklerinin metafizikten ahlâka siyasetten hukuka kadar ilke ve kurallarını belirleyen en temel kavramdır. Bu kavram her ne kadar modern dönemlerde yaygın bir şekilde hukuk ve siyaset terminolojisi ile ilişkilendirilerek kullanılsa da felsefî altyapısıyla düşünüldüğünde bireysel ve sosyal hayattan varlıktaki eşsiz denge ve düzene kadar mana zenginliğini bünyesinde barındıran yelpazesi geniş bir kavramdır. Arapça bir kelime olan adâlet "a-d-l" kökünden türemiş olup geniş manasıyla "bir şeyi yerli yerine koyma" anlamına gelir. Terim itibariyle "bireysel ve toplumsal yaşamda düzenlilik, hakkaniyet ve eşitlik ilkelerine uygun yaşamı temin eden erdem” olarak tarif edilir. ${ }^{1}$ Bir hukuk kavramı olarak adâlet "hakkın büyüğüne küçügüne, insanın itibar düzeyine bakılmaksızın eșitlik ilkesi gereğince yani sadece insanlık ortak paydasında buluşarak hakkı teslim etmeyi”, ahlâk kavramı olması yönüyle "bütün erdemlerin belirleyicisi olan yüksek bir ahlâkî erdem, bireyin ve içinde bulunduğu toplumun düzeni, tesisi ve devamı için en gerekli unsur,

1 İbn Manzûr, Lisânu'l-Arab (Beyrut: Daru's-Sadr, 1990). 11/430; Mustafa Çağrıc1, “Adâlet”, Türkiye Diyanet Vakfi İslâm Ansiklopedisi (istanbul: TDV. Yayınları, 1988) 
yetkinliğin kazanılmasını sağlayan temel erdem" şeklinde tanımlanabilir. Ahlâktan hukuka, siyasetten ekonomiye hayatın bütün alanlarını ilkeleriyle belirleyen kilit bir role sahip olan ve bireyin diğerleriyle, toplumla ve hatta devletle ilişkilerinin çerçevesini çizme noktasında anahtar bir kavram olan adâletin gerekliliği tartışılmaz bir gerçekliktir. Ancak adâletin kime ne şekilde uygulanacağı, toplumda nasıl tesis edileceği gibi uygulamaya yönelik hususlarda tarih tecrübesinin şahitliğiyle çok farklı yaklaşımların olduğu da bir gerçektir.

Felsefe geleneğinde genellikle teorik düzeyde ideal anlamıyla ele alınan adâlet kavramının İslam düşünce geleneğinde fikı h ve siyaset gibi uygulamalı alanlarda pratik hayattaki sorunlara çözüm üretme noktasındaki önemi ayrıca dikkate değerdir. Zira Müslüman toplumlarda adâletin mahiyetini ilgilendiren metafizik yönüyle yapilan felsefî tartışmaların ilmî çevrelerde devam ettiği bilinmekle birlikte adâletin daha çok siyasî ve hukukî yönüyle ilgilendikleri, sosyal ilişkileri ve devletin teşkilat yapısını adâlet ilkesinin rehberliğinde düzene koydukları da bir gerçektir. ${ }^{2}$ Mesela düşünce geleneğimizde siyasetnâme ve nasihatnâme türü metinleriyle mâruf, yaşadığı çağda devlet geleneğini bilen ve yönetim deneyimi bulunan düşünürler Müslümanların kutsal metinlerinin yol göstericiliğiyle siyasete adâlet zaviyesinden bakmışlar, siyasetin ahlâk, din ve özellikle fikıhla ilişkisi üzerine vurgu yaparak ilkelerini belirleme noktasında değerli bir çaba içerisinde olmuşlardır.

Bu makalemizde ${ }^{3}$ kendi döneminde fikıh ve siyaset başta olmak üzere pek çok sahada kıymetli metinleriyle Ortaçağ siyaset biliminin önemli düşünürlerinden biri olan Ebu'l-Hasan Ali bin Muhammed bin Habib el-Mâverdînnin (364-450/974-1058) düşünce dünyasının belirleyici kavramlarından "adâlet" anlayışını irdeleme gayesindeyiz. Nitekim o, siyasete dair kaleme aldığı eserlerde adâletin yol göstericiliğinde birey-devlet, devlet-birey ilişkisini belirleme çabasında olmuştur. Mesela yönetim ilkelerine dair kamu idaresi niteliğinde bir eser olan Ahkâmü's-sultaniyye ve'l-vilâyâtü'd-diniyye'de devlet başkanlığı, vezirlik, valilik, mezâlim mahkemeleri gibi devletin ideal yapısını tesis etme adına kurumların hangi temeller üzerine bina edilmesi gerektiği üzerinde durmuş; devletin teşkilatı, hukukî, idarî ve malî yapısıyla ilgili konuları ele almıştır. Edebü’d-dünya ve’d-din'de dinîve dünyevîahlâk ölçülerine ve toplumun ahlâkının nasıl tesis edileceğine dair nasihatlerde bulunmuş; Kavânînül-vizâre ve siyâsetü'l-mülk (Edebül-vezir) isimli eserinde devlet idaresindeki vezirlerin sahip olması gereken meziyetler ve uymak zorunda

\footnotetext{
Macid Haddûrî, İslâm'da Adâlet Kavramı, trc. Selahattin Ayaz (İstanbul: Yöneliş Yayınları, 1991). 31.

3 Mâverdînnin adâlet anlayışı ile ilgili çalışmalar için bkz. Mehmet Evkuran, "Mâverdînnin Düşünce Dünyası”, Doğudan Batıya Düşüncenin Serüveni (İstanbul: İnsan Yayınları, 2015), 5/1197-1222; Vecdi Akyüz, "Mâverdî ve Hukuk”, Doğudan Batıya Düşüncenin Serüveni (İstanbul: İnsan Yayınları, 2015), 5/1175-1196; İbrahim Barca, İslam Kurumları Tarihi Açısından Ebü'l-Hasan Ali b. Muhammed b. el-Habib el-Mâverdî el-Basrînin Kavânînül-vizâre ve siyasetü'l-mülk” Adlı Eseri (Yüksek Lisans Tezi, Şanlıurfa 2012); Cengiz Kallek, "Mâverdînin Ahlâkî, İçtimaî, Siyasî ve İktisadî Görüşleri”, Divan Disiplinlerarası Çalışmalar Dergisi 14 (2004), 219-265; Mustafa Sarıbıyık, Mâverdînin Nasihatü'l-mülûk'u ve Siyasî Görüşleri (Doktora Tezi, Selçuk Üniversitesi, 1996); Mehmet Birsin, Mâverdînin Devlet Anlayışı (Doktora Tezi, Ankara Üniversitesi, 2004); Mustafa Çağrıcı, "Mâverdî̀de Siyaset Ahlâk1", İslamiyât 6/1 (2003), 71-92.

4 Mehmet Erkal, “Ahkâmü’s-sultaniyye”, Türkiye Diyanet Vakfi İslâm Ansiklopedisi (İstanbul: Türkiye Diyanet Vakfi Yayınları, 1988), 1/555-556.
} 
oldukları kuralları belirlemiş; Teshîlü’n-Nazar ve ta'cîlü'z-zafer'de devlet ahlâkı, kamu yönetimi ve siyaset idaresiyle ilgili hususlara değinmiştir.

Engin siyaset ve diplomasi tecrübesiyle Mâverdî, eserlerinde siyaset, yönetim/yönetici ahlâkı, adâletli hükmetme gibi konulara özellikle değinmiştir. Ancak o, felsefe geleneğinde olduğu gibi siyaseti teorik ve ideal/ütopik zeminde tartışmamakta, gerek siyaset ve gerekse ahlâk konularında sonuca yönelik pratik bir tutum sergileyerek uygulamalı bir siyaset yaklaşımı ortaya koymaktadır. Nitekim döneminin siyasîleriyle yakın diyalog kurmasından dolayıdır ki siyaset ve yönetim ahlâkıyla ilgili değerlendirmeleri ve ileri sürdüğü çözüm önerileri genellikle devlet tecrübesinin bir yansıması olarak karşımıza çıar. Buna ilaveten o, Meşşâî felsefî mirasından farklı olarak İran, Hint siyaset düşüncesini İslam'ın ilkeleri ile birleştirmeye çalışan bir damarı temsil etmektedir. Zira metinlerinde genellikle Hz. Peygamber'in hadislerinin yanında Hz. Ömer, Hz. Ali gibi halifelerin sözlerini aktarır; yaygın şekilde Ardeşir bin Babek, Nuşirevan, Kisra, Büzürkmihr, İskender gibi eski İran coğrafyasında tanınan kralların ve önderlerin sözlerine ve yer yer Fars, Hint atasözlerine yer verir. ${ }^{5}$ Düşünürün İslam siyasî düşüncesinde döneminden önceki görüşleri tutarlı bir teorik çerçeveye ulaştırarak imamet/hilafet anlayışının şekillenmesine katkıda bulunan öncü isimlerden biri olduğunu söylemek de mümkündür. ${ }^{6}$

Ahlâkî ve siyasî boyutlarıyla "adâlet” kavramını irdeleyen Mâverdî kavramın daha ziyade yöneten-yönetilen ilişkisi bağlamında siyasette tazammun ettiği içeriğe ve çerçevelediği ilkelere yer vermiştir. Bunu yaparken realist bir tutum sergileyen düşünür kendi döneminde mevcut siyasî durumun analizini kanımızca güzel bir şekilde yapması, yöneticilere ve topluma yol gösterici nasihatler vermesi nedeniyle güncelliğini hiçbir zaman yitirmeyen bir adâlet yaklaşımı ortaya koymuştur.

\section{Ahlâkî Bir Değer Olarak Adâlet}

Ahlâkın kaynağının ve dinî sorumlulukların temel şartının akıl olduğunu ileri süren Mâverdî insan nefsinin eğitilebilir oluşu nedeniyle nefsten iki yapının ortaya çıktığını belirtir. Bunlardan birincisi nefste var olup çeşitli durumlarla ortaya çıkan ahlâk (ahlâkü'zzât), ikincisi akıl ve hevâ gibi unsurların yönlendirdiği iradeli davranışlardır (ef âlü'lirade). ${ }^{7}$ Ahlâkü'z-zât karakter ahlâkının elde edilmesi itibariyle doğuştan gelen ahlâk (ahlâkü'l-garîziyye) ve kazanılmış ahlâk (ahlâkü'l-muktesebe) şeklinde ikiye ayrılır. Doğuştan gelen ahlâk ile fitrî olarak sahip olunan eğitim yoluyla sonradan kazanılmamış güzel huylar kastedilmektedir. Buna "ahlâkü’t-tab" ve "hulukun matbûun" isimleri de verilir." Eğitim yoluyla elde edilen ve karakterin ayrılmaz parçası olan ahlâk ise kazanılmış (mükteseb) ahlâktır. ${ }^{9}$ Insanın davranışlarında kendi güç ve kudretinin etkisi olmadı̆̆ı gibi bir

5 Mehmet Evkuran, “Mâverdînnin Düşünce Dünyası”, Doğudan Batıya Düşüncenin Serüveni (İstanbul: İnsan Yayınları, 2015), 5/1210.

6 Vecdi Akyüz, "Mâverdî ve Hukuk”, Doğudan Batıya Düşüncenin Serüveni (İstanbul: İnsan Yayınları, 2015), 5/1179.

7 Mâverdî, Teshîlün-nazar ve ta'cilü'z-zafer fi ahlâki'l-melik ve siyâseti'l-mülk (Beyrut: Dâru'n-nahdati'l-Arabiyye, 1981), 5-6.

8 Mâverdî, Teshîlü'n-nazar, 8-10.

9 Mâverdî, Teshîlü'n-nazar, 10. 
görüşe karşı çıkan Mâverdî insanın kimliği, nereden gelip nereye gittiği akıbetinin ne olacağı gibi varoluşunun anlamına dair sorulara bulduğu cevaplar onun ahlâken neleri yapması ve hangi değerlere sahip olması gerektiğine dair bir sonuca götürür. Mâverdîye göre ahlâkın kaynağı her ne kadar akıl olsa da toplumdaki bireylerin ahlâkî yaşayışları birbirinden farklıdır. Kimileri davranışlarını kontrol altında tutarak güzel davranışlar sergilese de kimileri için ahlâkî davranışları belirleyip ona uymak için akıl tek başına yeterli bir ölçüt değildir. Bu durumda toplumsal uyumu bozmamak ve olumsuz davranışların önüne geçmek için dine ve diğer toplumsal kontrol mekanizmalarına ihtiyaç vardır. ${ }^{10}$ Böylelikle Mâverdî bir taraftan toplumda bireylerin davranışlarını düzene sokacak ahlâk ilkelerinin uygulanmasında yöneticinin sorumluluğunu vurgularken, diğer taraftan belirlenen ahlâkî normlara uygun yaşam konusunda sorumluluğu insana verir.

Mâverdîye göre öncelikle kişi kendisine karşı adâletli olmalıdır. Bu ise kişinin yaşadı̆̆ı olaylarda aşırılık ile eksiklik/yetersizlik arasında itidal noktasında durması, kendisini iyi ve güzel olana yönlendirmesi, kötülüklerden alıkoymasıyla mümkündür. İnsanın davranışlarında dengeli olanı tercih etmesi adâlet olduğundan dolayı kendinde iyi ve güzel davranışları gösteremeyen kimse kendine zulmetmiş olur. Kendine zulmeden kimse başkalarının hakkına riayet etmeyerek onlara daha adâletsiz davranır. ${ }^{11}$ Bu konuda felsefî geleneği takip eden düşünür adâlet ile itidal arasında ilişki kurarak adâletin itidalden alınd1ğını ve itidalin de iki erdemsizliğin (rezîlet) ortası olduğunu ifade eder. Erdemler akıl, cesaret (şecâat), iffet ve adâlet şeklinde dört temel erdeme dayanmakla birlikte, bütün erdemlerin başı akıl sonu ise adâlettir. Diğer bütün erdemlerin bu erdemlerle ilişkisi olup bütün erdemler bu iki erdem arasında yer alır. ${ }^{12}$ Buna göre hikmet kötülük (şer) ile bilgisizliğin (cehâlet), cesaret (şecâat) gözüpeklik (tehevvür) ile korkaklığın (cebânet), iffet şehvet azgınlığı (șereh) ile zayıflığın, huzur (sekînet) kızgınlık ile zayıf öfkenin, tevâzu kibir ile aşağılık duygusunun (denâetü'n-nefs), cömertlik israf (tebzîr) ile cimriliğin; halimlik aşırı öfke (gadab) ile öfkesizliğin (ademü’l-gadab) ortasıdır. Ortaya çıkan bir bozulma (fesat) aşırılık veya azlık yoluyla adâletsizliğe düşmenin bir sonucudur. Böylelikle bireyin ahlâkını geliştiren en faydalı erdem adâlet ve en zararlısı da adâletsizliğe düşmektir. ${ }^{13}$ Mâverdîye göre erdemlerin başka erdemlerle birleşmesinden yeni erdemler ortaya çıkar. Mesela akıl ve cesaretin birleşmesinden ahde vefa ve sabır, akıl ve iffetin birleşmesinden saygınlık, cesaret ve iffetin birleşmesinden kötülüğe karşı koyma, cömertlik ve iffetin birleşmesinden de yardımseverlik gibi erdemler ortaya çıkar. ${ }^{14}$

\section{Bir Siyaset İlkesi Olarak Adâlet}

Felsefeye dair klasik dönem eserlerinde, ahlâk ve siyaset alanının birbirini bütünleyen iki alan olduğu görülmektedir. Mesela Aristoteles'e nispet edilen Büyük Ahlâk

10 Mâverdî, Edebü'd-dünya ve'd-din (Beyrut: 1985), 148.

11 Mâverdî, Edebü'd-dünya ve'd-din, 148.

12 Mâverdî, Teshîlï'n-nazar, 17-18.

13 Mâverdî, Edebü'd-dünya ve'd-din, 156-157; Teshîlün-nazar, 17-18; Vecdi Akyüz, "Mâverdî ve Hukuk". 5/1193.

14 Mâverdî, Teshîlü'n-nazar, 18-19. 
(Magna Moralia) da, ahlâktan bahsedilecekse ilk olarak ahlâkî yapının incelenmesi gerektiği ve bunun da gerçekte siyasetin konusu olduğu ifadesiyle başlar. Yine bu eserde ahlâkın ilmî bir disiplin olmakla birlikte siyasetin de girişi olduğu ifade edilir. ${ }^{15}$ Mâverdînnin düşünce dünyasında da ahlâk ve siyasetin birbirini tamamlayan iki alan olduğunu görmek mümkündür. Bu iki alanın kurallarını belirleyen ise ona göre dindir. Nitekim Mâverdî siyasetin ve ahlâkın temel ilkesi olarak gördüğü adâleti dinî referanslarla takviye ederek gerekliliğini açıklamaktadır. Hikmet sahiplerinden birisine: "Hangi hayır en vefalıdır?" diye sorulduğunda o cevaben, "dindir" demiş. Ona: "En kuvvetli güç hangisidir?" diye sorulduğunda ise cevaben, "adâlettir" demiștir. ${ }^{16}$ Dolayısıyla din ve adâlet duygusu bireyin ahlâkî yapısının şekillenmesinden yöneticinin uyguladığı siyasete kadar bütün bir alanın en temel iki kavramıdır.

Aslına bakılırsa İslam düşünce geleneğinde adâlet kavramı dinî içeriğiyle daha zengin kılınmış bir kavramdır. Zira Müslümanlar Kur'ân ve Sünnetteki çerçevesinden hareketle adâleti yorumlamış, böylelikle adâlet İslâm toplumlarına özgü siyasal bir kavrama dönüşmüştür. ${ }^{17}$ Ancak İslâm dini siyasal organizasyonu ilke olarak kabul etmekle beraber adâlet düşüncesinin hangi kurumda nasıl işlemesi gerektiği hususunda açık hükümler koymamıştır. Adâletin esas alınarak uygulanması hususunda naslardan açık emirler alan Müslümanlar, siyâsî yapının kurumlaşma aşamasında ve uygulamada adâletin vazgeçilmez bir ilke olduğunu kabul etmişlerdir. Bununla birlikte her dönemde siyasal yapının temel kurumsal bir unsuru olarak ortaya çıkışı, teorik temellendirmeden sonra gerçekleşmiştir. ${ }^{18}$ Bu minvalde Mâverdîilk olarak siyasal yapının oluşum sürecinin teorik temellerini tartışır. Ona göre medenî bir varlık olan insan birbirine muhtaç yaratılmış olup diğer insanlarla bir arada yaşamak zorundadır. Felsefî ahlâk literatüründe sıkça karşılaştığımız bu ihtiyaç doktrini yaklaşımı insanın toplumsallaşmasının nedeni olarak görülür. Nitekim toplum aslında ihtiyaçlarını tek başına karşılama konusunda yetersiz bireylerden oluşmakta bu ise işbölümü yapmayı zorunlu kılmaktadır. Tabiatı itibariyle insanın, kendini kıstlayan ve zorlayııı bir unsur bulunmaksızın içinde bulunduğu toplumun faydasını gözetmeye matuf diğer insanlarla bir uzlaşı ve uyuşma zemininde buluşması oldukça zordur. ${ }^{19}$ Zira Allah kullarını âciz ve kendisine muhtaç olduklarını fark etsin diye birbirine muhtaç halde yaratmıştır. Birbirlerinden farklı donanımlarda olan ve aynı zamanda yardımlaşmaya ihtiyacı olan insanoğlu doğal olarak devleti oluşturmaya yönelmektedi ${ }^{20} \mathrm{ki} \mathrm{bu} \mathrm{da} \mathrm{bize} \mathrm{siyaset}$ sisteminin ve dolayısıyla bir yönetim etrafında buluşmanın gerekliliğini gösterir.

15 Aristotle, Magna Moralia (The Works of Aristotle IX), ed. W. D. Ross (Londra: Oxford University Press, 1949). 1181a-1181b.; Hümeyra Karagözoğlu, Ahlâk Düşüncesinde Siyaseti Aramak: İbn Miskeveyh'le "Adâlet" Kavramının Siyasi Yansımaları, Divan Disiplinlerarası Çalışmalar Dergisi 14/27 (2009), 94.

16 İbrahim Barca, İslam Kurumları Tarihi Açısından Ebüll-Hasan Ali b. Muhammed b. el-Habib el-Mâverdî el-Basrînin Kavânînül-vizâre ve siyasetü'l-mülk” Adlı Eseri (Yüksek Lisans Tezi, Şanlıurfa 2012), 60.

17 Ejder Okumuş, “Osmanlılar'da Siyasal Bir Kurum Olarak Adâlet Dairesi”, Sosyal Bilimler Araşttrma Dergisi, 3/5 (2005), 46.

18 Yunus Kaplan, “Osmanlı'da Adâlet Mefhumunun Kökenleri”, Journal of Islamic Research 31/1 (2020), 155.

19 Mâverdî, A'lâmü’n-nübüvve, nşr. Muhammed el-Mu’tasım-Billâh el-Bağdâdî (Beyrut 1407/1987), 42.

20 Mâverdî, Edebü'd-dünya ve'd-din. 144-148. 
İhtiyaçların karşılanması sâikiyle kurulan toplumun bireylerini birbirine bağlayan unsur maddî ilişkiler olmakla birlikte insan ilişkilerinde ortaya çıkan rekabet ve çekişmeleri düzenleyecek daha aşkın bir değer üzerinde birleşmek gerekmektedir. Mâverdîye göre insan dünyanın imarı noktasında hemcinsleriyle yardımlaşmak istediğinde tahakkuk etmesi gereken âmillerin başında din gelir. Nitekim insana iç huzur veren din insanları birbirleriyle güzel geçinmeye, iyi ilişkiler kurmaya çağırır; günah ve kötülüklerden uzaklaştırır. Zira kendiyle barışık olmayan insanın ne kendisini ne de çevresini islah etmesi beklenmez. ${ }^{21}$

\subsection{Yönetim Ahlâkı Açısından Adâlet}

Ahlâk denildiğinde her ne kadar bireysel ahlâk anlaşılsa da dinî ve dünyevî iyilikleri temin etmek amacında olan siyasetin ilkelerini belirleyen kurallar ahlâk ve adâlet üzerine olmalıdır. Yönetici yetkilerini doğru bir şekilde kullanarak topluma güzel örnek olup toplumun ahlâkını geliştirmeli ve halkının gözünde iktidarını meşru kılabilmesi için üstün bir ahlâka sahip olmalıdır. ${ }^{22}$

Siyasetin ahlâka duyduğu ihtiyacı yakından bilen bir düşünür olarak Mâverdî bürokrasiye ahlâkî bir ruh aşılamaya çalışmıştır. Zira o yaşadığı dönemde ulaşabildiği siyasî birikimleri inceleyerek etkili ve gerçekçi bir yönetim teorisi kurmayı hedeflemiş ${ }^{23}$ bunu yaparken de adâleti devlet yönetiminin en birinci ilkesi olarak görmüştür. Mesela Ahkâmü’sSultaniyye'nin giriş kısmında hilafetin tanımı, halife olacak kimselerde bulunması gereken özellikler, halifenin seçim şekli, görev ve sorumluluklar1 ${ }^{24}$ gibi konulara değinen Mâverdî halifenin en birinci özelliğinin her yönüyle adâletli olması, ${ }^{25}$ halifeyi seçecek kurulun (Ehlü'l-hall ve'l-Akd) heyeti üyelerinde bulunması gereken şartlardan birincisinin de "her yönüyle doğrulukla bilinip adâletle ilgili bütün şartları taşımak"26 olduğunu ifade eder. Yine yöneticileri hedeflerine ulaştıracak en önemli araç da ahlâk olmalıdır. Nitekim erdemli fiiller ancak yüksek ahlâka sahip olanlardan çıkar. ${ }^{27}$ Mâverdî̀ye göre devlet başkanı makamının gereği olarak -her ne kadar zor ve ağır görev olsa da- dinin emirleri doğrultusunda halkına karşı eşit davranmalı ve adâletiyle önder ve örnek kişi olmalıdır. ${ }^{28}$ Yine başka bir metinde Mâverdî, devlet başkanının zâlimin aşırılıklarını mazlumun zayıf düşmesini engellemek suretiyle adâleti sağlaması, ${ }^{29}$ bu görevi yerine getirmediğinde yani yönetimde adâletten saptığında görevden alınması gerektiğini ${ }^{30}$ söyleyerek konunun ehemmiyetini vurgulamıştır.

\footnotetext{
21 Cengiz Kallek, “Mâverdînnin Ahlâkî, İçtimaî, Siyasî ve İktisadî Görüşleri”, Divan Disiplinlerarası Çalışmalar Dergisi 14 (2004), 235-236.

22 Mâverdî, Teshîlü'n-nazar, 135.

23 Mehmet Evkuran, "Mâverdînin Düşünce Dünyası", Doğudan Batıya Düşüncenin Serüveni, 5/1213.

24 Mâverdî, Ahkâmü's-sultaniyyeve'l-vilâyâtü'd-diniyye. thk. Ahmed Mübarek Bağdâdî (Kuveyt: Dâru İbn Kuteybe, 1989), 5-10.

25 Mâverdî, Ahkâmü's-sultaniyye ve'l-vilâyâtü'd-diniyye, 5.

26 Mâverdî, Ahkâmü's-sultaniyye ve'l-vilâyâtü'd-diniyye, 7-8.

27 Mâverdî, Teshîlün-nazar, 135-138.

28 Mâverdî, Ahkâmü's-sultaniyye ve'l-vilâyâtü'd-diniyye, 5.

29 Mâverdî, Ahkâmü's-sultaniyye ve'l-vilâyâtü'd-diniyye, 22.

30 Mâverdî, Ahkâmü's-sultaniyye ve'l-vilâyâtü'd-diniyye, 24.
} 
Mâverdî yönetimde görevli kimselerin adâletli oluşunu dinî emirlerle ilişkilendirmektedir. Zira ona göre adâletli olmak kişinin güvenilir olması, haram şeylerden ve günah işlemekten sakınması, şüpheli şeylerden uzak durması, dinî ve dünyevî işlerinde aynı olgunlukla hareket edebilmesidir. ${ }^{31}$ Dolayısıyla adâlet kişinin sahip olduğu dinî değerlerle belirginleşir, yönetimde adâletli davranıp davranmayacağı da kişisel olarak sahip olduğu niteliklerle ilişkilendirilir. Bununla birlikte dini araçsallaştırmak suretiyle din aracılığıyla siyasî bir çıkar elde etme ve ihtiraslarını geçekleştirmesi asla doğru değildir. Nitekim yöneticinin yeryüzünde Allah'ın vekili olarak görüldüğü bir siyaset yaklaşımında yöneticinin kutsallığından çok dine karşı sorumluluğu ön plandadır. Yönetici Allah'ın vekili olduğuna göre dinin emirlerinden yüz çeviren ve yasaklarına muhalefet eden bir yöneticinin işlerinin düzelmesi ve başarılı olması mümkün değildir. İnsanlar arasında adâletle hükmetmek, peygamberin sünnetine uymak, kamuya ait işleri idare etmede akıllıca davranmak ve gereken tedbirleri almak yöneticilerin temel sorumluluğudur. ${ }^{32}$

Halifelik müessesesini imamet olarak isimlendiren Mâverdî bu müessesenin dinî ve dünyevî işlerin yürütülmesi için nübüvvet mesleğine halef olarak tesis edildiğini belirtir. Bu açıdan devlet başkanlığı görevini yürüten kimseye bütün Müslüman topluluğunun uyması dinen gereklidir. Zira devlet başkanlığı görevinde bulunanlar din ve dünya faydasını gerçekleştirme gayesi içindedir. Bunun için devlet başkanı ahlâkî meziyetlerle donanmalıdır. ${ }^{33}$ Zira Müslüman toplumlar siyasî adâletin gerçekleşmesini ilâhî adâletin yeryüzünde bir yansıması olarak görmekte, imameti de kamu düzeninin sağlanmasını sağlayan bir araç olarak değerlendirmektedir. ${ }^{34}$ Yöneticiler erdemleriyle kendilerini yüceltmiş, ruhlarını arındırmış kimselerden olmalıdır. Nitekim Hulefâ-i Râşidîn ahlâk ve adâlet itibariyle en üstün özellikte olduklarından dolayı halkı yönetmeye hak kazanmışlardır. Halk iyilik ve kötülükte yöneticilerini örnek/model alacaklarından dolayı yöneticilerin yüksek bir ahlâka sahip olması gerekir. Nitekim Mâverdî bu konuda "Emirler ve hükümdarlar daima ahlâklarını ve erdemlerini arttırmalıdır. Çünkü halk işlerinde ve hükümlerinde kötülükte ve iyilikte, ciddiyet ve mizahta onlara tabi olurlar" der. ${ }^{35}$

Görüldüğü üzere Mâverdî adâleti ahlâkî bir erdem olmasının yanında devletin temel bir görevi olarak faaliyet alanlarında tesis etmesi gereken ilke kabul eder. Zira adâlet toplumu oluşturan bireylerin birbirleri arasında ve yöneten-yönetilen arasındaki ilişkide kuralları belirleyen temel bir ilkedir. Kavâninü'l-Vizâra isimli eserinde vezirlere nasihatte bulunan düşünür onların adâletli olduğunda halkın da onlara itaat edeceğini, hesaba çekerken zulmeden kimsenin kendisi de hesaba çekilince zulme uğrayacağını belirtir. Mâverdîyönetici-yönetilen ilişkisinde adâletin gerekliliğini "kim bir kötülükte bulunursa yaptığı kötülüğün karşılıksız kalmayacă̆ı” gibi dinî referanslarla da güçlü bir

31 Mâverdî, Ahkâmü's-sultaniyye ve'l-vilâyâtü'd-diniyye, 89

32 Mehmet Evkuran, “Mâverdî’nin Düşünce Dünyası”, Doğudan Batıya Düşüncenin Serüveni, 5/1213.

33 Mâverdî, Teshîlü'n-nazar, 135.

34 Muhammed Hamidullah, İslâm'da Devlet İdâresi, trc. Hamdi Aktaş (İstanbul: Beyan Yayınları, 2007). $26-27$.

35 Mâverdî, Teshîlü’n-nazar. 104, 134-135, 203; Osman Karaca, Mâverdînin Ahlâk Görüşü, (Yüksek Lisans Tezi, Van, 2008), 99. 
şekilde vurgular. Yine devlet idaresinde ekonominin adâletle ilişkisine değinip gelirlerin çoğalmasının yolunun ancak adâlet olduğunu zulüm ve haksızlıkla devlet gelirlerinin azalacağını ileri sürer. Devlet gelirlerinin idaresinde görevlendirilecek kişilerin belirlenmesinde de temel kriter adâlet, güvenilir olmak, işin gerektirdiği liyâkata sahip olma olmalıdır. Bu meyanda Mâverdî hikmetli bir söze yer verir "Adâlet ve insaf bir arada yaşamanın süresini belirler." Toplumda adâlet ilkesi esas olduğunda o toplumun ömrü uzun olur. ${ }^{36}$ Yine Edebü'd-dünya ve'd-din'de edebi değerlendirirken farzların edasını sağlayan "şeriat edebi" ve ülkenin bayındır hale gelmesini sağlayan "siyaset edebi" şeklinde ikiye ayırır. Bu ikisinin esası olan adâlet ise toplumsal barış (selâmetü's-sultân) ve ülkenin bayındır (imârâtü'l-buldân) hale gelmesini sağlayan temel esastır. Zira farzları yapmayan kişinin kendine zulmettiği gibi ülkeyi tahrip eden de başkasına zulmetmiş olur. ${ }^{37}$

Bir arada yaşamanın vazgeçilmez ilkesi olan adâletin insan ilişkilerinde pek çok yönü vardır. Örneğin toplumdaki bireyler sözlerinde, eylemlerinde; yöneticiler gelir paylaşımında, hukukta adâlete uygun davranmalıdır. Gelir ve giderler konusunda adâletli olmak gelirleri hak sahiplerine adâlete uygun bir şekilde dağıtmak, konuşmada adâlet erdem sahibi âlim insanlarla cahil/bilgisiz insanlar gibi muhatap olunmaması, teşvik ve tehdit içeren ifadelerde aşırılıklara (ifrat-tefrit) düşmeden gerektiği kadar konuşulmasıdır. Fiillerde adâlet ise cezanın bir suç karşılığında affın da bir af dileme/tövbe karşılı̆̆ında olması şeklindedir. Yine öfke ve sevinç hallerinde adâletten ayrılmamak öfkenin iyilikleri, sevinmenin de kötülükleri görmeye engel olmamasıdır. Mâverdî yönetici/peygamber modeli olarak Süleyman b. Davud'un "bana ihsan edilen en faziletli şeyler; öfke ve rıza halinde haktan ayrılmamak, fakirlikte ve zenginlikte iktisatlı olmak, gizli ve açıkta Allah'tan korkmaktır." ${ }^{38}$ şeklindeki sözünü hatırlatarak her durumun kendine göre dengeli oluşunun adâlet olduğuna işaret eder.

Toplumsal düzeni sağlamanın dinî, siyasî, hukukî, inzibatî, iktisadî ve beşeri olmak üzere çeşitli yönleri olduğunu belirten Mâverdî toplumsal barış, birlik ve dirlik için şu esasların gerekliliğini üzerinde durur. Bunlar kendisine uyulan din (dinün mütteba'), muktedir sultan (sultânun kâhir), kapsamlı adâlet (adlun şâmilün), genel emniyet (emnun âmm), sürekli bolluk (hasbun dâim) ve geniş emeldir (emelun fesîh). ${ }^{39}$ İnsan, bu ilkelerin esas alındı̆̆ı bir toplumda mutlu, huzurlu, refah ve güven içinde medenî bir hayat yaşar. Aslına bakılırsa bu ilkelerin her biri toplumda adâletin -mana zenginliğiyle düşündüğümüzdesağlanması ile ilgilidir. Ancak Mâverdî, adâletin hukuk devleti çerçevesinde toplumun tamamını kuşatması için kapsamlı adâlet ilkesine ayrıca vurgu yapmıştır.

Siyaset kurumunun topluma karşı sorumluluğunun farkında olan Mâverdî için yöneticinin en önemli görevlerinden biri toplumda güçlü-zayıf, asil-sıradan, havas-avam ayrımı yapmadan sınıflar arası çatışma olmaksızın hukuk önünde herkesi denk tutmak

\footnotetext{
36 İbrahim Barca, İslam Kurumları Tarihi Açısından Ebül-Hasan Ali b. Muhammed b. el-Habib el-Mâverdî el-Basrînin Kavânînül-vizâre ve siyasetü'l-mülk” Adlı Eseri, 60, 101.

37 Mâverdî, Edebü'd-dünya ve'd-din, 148-149.

38 İbrahim Barca, İslam Kurumları Tarihi Açısından Ebü'l-Hasan Ali b. Muhammed b. el-Habib el-Mâverdî el-Basrînin Kavânînül-vizâre ve siyasetü'l-mülk" Adlı Eseri, 60.

39 Mâverdî, Edebü'd-dünya ve'd-din. 148; Vecdi Akyüz, "Mâverdî ve Hukuk", 1196.
} 
olmalıdır. Bu konuda devlet başkanı Allah'ın emrine uymalı, toplumda zulüm ve baskının önüne geçmeli, kendi aleyhine gelişen durumlarda bile insaflı davranıp haklının hakkını vermelidir. ${ }^{40}$ Hatta bir zulüm yapmış ve hasmı kendisinden davacı ise Müslüman halifelerin ve Sasânî kralların uyguladığı gibi hâkimin huzurunda mahkeme olunmalı, haksı görülürse de hasmına hakkını ödemelidir. ${ }^{41}$ Yönetimin güçlü olması ve gücün dengesiz kullanımıyla ortaya çıkabilecek haksızlıkları ortadan kaldırmak için bu esas çok önemlidir. Mâverdî devletin güçlü olmasını savunmakla birlikte gücün yersiz kullanılmasının neticesinde çıkabilecek yanlışlıkları bertaraf etmek için kapsamlı adâlet ilkesini getirmiştir. ${ }^{42}$ Kapsamlı adâlet ile Mâverdî adâleti iktidarın gücü ve meşruiyeti için dengeleyici bir unsur olarak görmüştür. Ona göre herkesi kuşatan adâlet toplumda düzenin ve birliğin tesisini sağlayan önemli bir ilkedir. Kapsamlı adâlet sayesinde halkın iktidara bağlılı̆̆ı artar, ülke bayındır hale gelir, ülkenin gelirleri artar, nüfus çoğalır; böylelikle devlet başkanı güven içinde olur. Bu şekilde adâlet siyasal yönetimin icraatlarının meşruluğunu temin eden bir araç haline gelir. Adâletsizlik (cevr) ise duracak bir sinırı olmadı̆̆ından insanların kalplerinin bozulmasını ve zamanla yeryüzünün harap olmasını netice verir. Dünyanın imârı ancak adâlette gerçekleşeceğinden dolayı insan ilk olarak kendisinden başlayarak adâleti tesis etmelidir. ${ }^{43}$ Nitekim insanın kendisine karşı adâletli olması bir yönüyle ahlâklı olma, kendine hâkim olması manasına gelir. Bu açıdan inananların üzerinde etki ve yaptırım gücü bakımından en önemli unsur "kendisine uyulan din"dir. Zira din nefsin arzularını (şehvet) dizginleyerek erdemli bireylerin yetişmesini sağlayan en önemli unsurdur. ${ }^{44}$ Aslına bakılırsa yukarıda zikredilen ilkeler içerisinde özellikle kendisine uyulan din ve kapsamlı adâlet ilkeleri toplumun düzeni ve selâmeti için birbirine yardımcı temel unsurlardır.

\subsection{Adâletli Yönetimin Esasları}

Mâverdî eserlerinde yönetimin adâlet üzerine kurulması ve yöneticilerin de bu ilkeden ayrılmaması gerektiği hususuna çokça vurgu yapar. Ancak yönetimin adâletli olmasını sadece hukuk devletinin değişmez yasaları ve kurumların sağlıklı organizasyonu ile mümkün görmez. Ona göre âdil bir yönetimin manevî dinamikleri, devlet ve toplumun gönül bağını güçlendirici unsurları olması gerekir. Bunun için de âdil yönetimi sağlamak adına dört temel hususa dikkat edilmelidir. Bunlar; rağbet (sevgi), rahbet (korkutmak), insaf (adâlet) ve intisaf (eşitlik). Rağbet toplumdaki bireylerin birbirleriyle kaynaşıp devlete ve yöneticiye gönülden bağlanmasına vesile olur. Yönetici de halkına gerekli sevgiyi gösterdiğinde halk nezdinde saygınlığını ve itibarını arttırmış olur. Çünkü sevgi bağı olmadığında yönetici ile halk arasında zorunluluktan kaynaklanan bir iletişim olur. Bu durumda halk

40 Mâverdî, Teshîlü'n-nazar, 233.

41 Mustafa Sarıbıyı, Mâverdî’nin Nasihatü'l-mülûk'u ve Siyasî Görüşleri (Doktora Tezi, Selçuk Üniversitesi, 1996), 78.

42 Mehmet Birsin, Mâverdînin Devlet Anlayışı (Doktora Tezi, Ankara Üniversitesi, 2004), 61-62.

43 Mâverdî, Edebü'd-dünya ve'd-din,153.

44 Mâverdî, Edebü'd-dünya ve'd-din, 148-149. 
yöneticiye korkusundan boyun eğer, yöneticiye karşı gizliden tepki oluşmaya bu da toplumda huzursuzluğa yol açar. Halkın yöneticiye açıktan tepkisi ise isyan, ayrılık ve dağılmalara neden olur.

İkincisi korkudur (rahbe). Yöneticinin otoritesini sağlayan en güçlü unsur olan korkutma sayesinde toplumda düzeni bozanların yönetime karşı düşmanlık yapmaları engellenir. Mâverdî’ye göre gerektiği yerde insanları korku ile uyarmak devletin düzeni ve istikrarı için gereklidir. Böyle bir güç toplumda karışıklık (fesat) çıkarmak isteyenleri engelleyici bir uyarıdır. Zira korkutma ile yönetici toplumu kötülüğe yönlendiren ve devlete muhalif olanların düşmanca eylemlerini engeller. Ancak toplumun düzeni için sevgi ile korkunun dengeli bir şekilde olması gerekir. Nitekim toplumda aşırı/yersiz korku zamanla isyana neden olabilecekken korkunun az olması otoritenin/siyasal iktidarın zayıflamasına neden olur. Ancak bu ikisi gerektiği yerde dengeli olursa yöneticinin otoritesi güçlenir, halkın yönetime karşı isyanının önüne geçilir, vatandaşların devlete bağlllığı ve geleceğe dair ümitleri $\operatorname{artar}^{45}$

Sevgi ve korku arasındaki dengeden üçüncü ilke olan adâlet (insaf) ortaya çlkar. Hak ile bâtılı birbirinden ayıran adâlet olmadan devletin ve halkın düzenini sağlamak mümkün değildir. Nitekim adâletin olmadığı yerde yönetim/otorite uzun süre ayakta kalmaz. ${ }^{46}$ Mâverdî bir filozoftan naklen adâlet dairesini andıran bir zincirle yönetim-liyâkat-halka ihsan-gelirin artması-adâlet arasında şöyle bir ilişki kurar. "Yönetim, ehliyetli görevlileri; ehliyetli görevliler ihsanda bulunmayı; ihsanda bulunma malı; mal ise adâleti gerektirir." Düşünürümüze göre halkını sıkıntıya sokacak şartları ortadan kaldıran, onlara güç kullanmaktan kaçınan ve daima hakkı gözeten bir yönetim şekli takip etmesi yöneticinin adâletinin göstergesidir. ${ }^{48}$ Mâverdî adâletin zıddı olan zulmün çirkin yüzünü adâletteki güzellikle ters orantılı görür. "Bilinmeli ki zulümdeki çirkinlik, adâletteki güzellikle ters orant1lıdır. Zâlimin yönetiminden uzak durmak, âdil kişinin yönetimine duyulan arzu ölçüsündedir. Zira halkın içinde bulunduğu durum ve devletin işleri ancak adâletli bir yönetimle düzene girer. Bu bakımdan sultana yakışan, yönetimine âdil kimseleri getirmek ve halkına ihsanda bulunmak suretiyle hüküm sürdüğü günlerin arzulanmasını sağlamaktır. Çünkü devletiyle halkına bedenen sahip olabilse de, gönüllerine ancak ihsanıyla sahip olabilir. ${ }^{49}$ Bu şekilde yönetici adâletin katı ve kesin kuralları olan bir ilkeler bütünü gibi anlaşılan sert yüzü yerine halkın refah içinde yaşamasını sağlamaya yönelik güzel yüzünü göstermelidir. Yine Mâverdî zulmü adâletinden çok olan, toplumdaki bireyler arasında adâleti sağlayamayan devletin uzun süre ayakta kalamayacağını, zira zulmün azının bile devletin kaderinde etkili olurken had safhaya ulaşmış zulümle devletin yok olmasını kaçınılmaz olarak görür..$^{50}$ Dolayısıyla zulmün egemen olduğu toplumda kaos, anarşi, huzursuzluk ve mutsuzluğun olması kaçınılmazdır.

45 Mâverdî, Teshîlün-nazar, 181-182.

46 Mâverdî, Teshîlïn-nazar, 182.

47 Mâverdî,Dürerüs'sülûkfísiyaseti'l-mülûk, trc. Abdüsselam Arı (İstanbul, Türkiye Yazma Eserler Kurumu, 2019), 16-17, 67-68.

48 Mustafa Çağrıcı, "Mâverdî'de Siyaset Ahlâkı", İslamiyât 6/1 (2003), 85.

49 Mâverdî, Dürerüs'sülûkfísiyaseti'l-mülûk, 103.

50 Mâverdî, Teshîlü'n-nazar, 182-184. 
Adâletli yönetim için yöneticinin dikkat etmesi gereken dördüncü ilke eşitliktir. (intisaf) Adâletin daha ziyade yarg1/hukuk önünde uygulanmasına karşılık gelen eşitlik her hak sahibine hakkını vermek ve bunu yaparken de zengin-fakir, asil/köle gibi sınıfsal bir ayrım gözetmeksizin hukuk önünde insanlara eşit davranmak manasına gelir. Yönetici bu şekilde halk arasında eşitliği gözettiğinde adâlet de sağlanmış olur. ${ }^{51}$ Devlet başkanı kanun önünde güçlü-zayıf, havas-avam ayrımı yapmaksızın kendisini de ayırt etmeden herkese eşit davranmak zorunda olup aleyhine de olsa adâletten ayrılmamalıdır. ${ }^{52}$ Adâlete dayanan bir idare için bu dört unsurun gerektiği yerde dengeli bir şekilde kullanılması toplumda düzen ve istikrarın sağlanması açısından büyük önem arz etmektedir.

Devlet yönetiminin sağlıklı ve amaca uygun bir şekilde işleyebilmesi için kurumlardan ziyade ilkelere önem veren Mâverdî adâleti icra edecek devlet organlarının adâletin dağıtımı konusunda ilkelerden vazgeçmemesi gerektiğine işaret eder. Nitekim yönetici bizzat kendisinden başlamak üzere adâlet düzeninde eşitlik ilkesine göre hareket etmeli, adâletin dağıtımını icra edecek kadıların tayinine ve hak kaybı yaşanmadan yargılamanın hızlandırılmasına dikkat etmelidir. ${ }^{53}$ Dolayısıyla insanlar arasındaki adâleti uygulamak, mazlumların hakkına riâyet ederek yargı sistemini liyâkate göre kontrol altında tutmak devlet başkanının görevidir. Nitekim Nasihâtü'l-Mülûk'ta devlette adâlet dağıtacak kadıların seçiminde liyâkatin çok önemli olduğunu vurgulayarak kadılık makamina gelecek kimsenin dindar, iffetli, âlim, fakih, basiretli ve güvenilir kimselerden seçilmesi gerektiğini hatırlatır. Hatta adayların durumu eşit ise eşitler arasında daha bilgili, takvâ sahibi ve ehliyetli olana öncelik verilmelidir. Kadı Allah'ın kitabını, Hz. Peygamber'in hadislerini, hukuk usûlü ve uygulamalarını da detaylı bir şekilde bilmelidir. Bütün bu hususlar adâleti icra eden yargı mensubunun ehliyet ve liyâkatinin adâleti sağlamadaki önemini göstermektedir.

Kadı yargılama esnasında inceleme ve araştırma yapmalı, acele hüküm vermemeli, dava ispatlandıktan sonra hükmün uygulanmasını geciktirmemelidir. Adlî davalarda kadının davayı geciktiremeyeceği gibi, yöneticinin de gözcülük ettiği mezâlim mahkemelerinde de dava geciktirilmemelidir. Eğer davaların görülmesi belirli günlerde yetişmiyorsa oturum günleri arttırılmalıdır. Zira davalar uzun sürerse insanlar rahatlıkla hukuka aykırı işler yapmaya devam ederler. Mazlumlar haklarını almadan ölebilir, zalimler de yargılanmadan kendini kurtarmış olabilir. ${ }^{54}$ Bu şekilde Mâverdî devlet yönetiminde hakkın küçügüne büyüğüne bakmaksızın hukuka uygun davranmayı devletin selameti için olmazsa olmaz bir şart olarak görür.

Mâverdî yönetici ile raiyyetindeki halk arasında dört tür ilişkiden bahseder. Birincisi yönetici ve halkın her ikisinin mutlu ve huzurlu olduğu türdür ki bunda yönetici ve halk üstün bir ahlâka sahiptir. Böyle bir yönetimde yöneticinin en önemli özelliği adâleti esas almasıdır, halk da yöneticiye ve kanunlara karşı saygılı ve itaatkârdır. İkincisi yönetici görevini yerine getirecek yeterlilikte iken halkın düzeni bozuktur. Böyle bir durumda yönetici gerekli tedbirleri almazsa zamanla devletin düzeni bozulur. Bunun için

51 Mâverdî, Teshîlün-nazar, 182-184.

52 Mâverdî, Teshîlü'n-nazar, 265.

53 Mâverdî, Ahkâmü's-Sultaniyye, 88-89.

54 Mustafa Sarıbıyı, Mâverdînin Nasihatü'l-mülûk'u ve Siyasî Görüşleri, 77-79. 
yönetici öncelikle halkı iyilikle doğru yola çağırmalı, bu netice vermezse katı tedbirler almalıdır. Bozulmuş bir topluluğa yöneticinin katı davranması onun adâletinin gereğidir. Üçüncü durumda ise halkın düzgün yöneticinin görevini layıkıyla yapmadığı durumdur ki bu, halkın huzursuz ve mutsuz olmasının sebebidir. Bu durumda halk adâletli bir idare için öncelikle yönetime gücünü hissettirmeli, yoksa adâletle idare edecek başka bir yönetici aramalıdır. Dördüncü durumda ise yönetici ve halkın her ikisinin bozuk olduğu toplumdur ki bu toplumda kargaşa hâkimdir, birbirini doğru yola çağıran kimse yoktur. Böyle bir toplumdan düzelme beklenemeyeceği için toplum yok olmaya mahkûmdur. Nitekim istikrar ve huzuru olmayan bir devletin varlığını devam ettirmesi mümkün değildir. ${ }^{55}$ Yönetici ve diğer devlet görevlileri Müslümanların canlarına, mallarına ve ırzlarına göz dikmemeli ve onlara şefkatle muamele etmelidir. Toplumun huzur ve selameti için yönetici halkına zulmetmemeli hatta halkını diğer devlet görevlilerinin zulmünden korumalıdır. Zira yöneticinin idaresi altındaki insanlara zulmetmesi onun için alçaltıcı bir davranıştır. ${ }^{56}$

Mâverdî devlet kurumlarında makamların kabiliyet ve liyâkat aranmaksızın babadan oğula intikaline karşı çıkmakta, makamların ehliyet esasına dayalı olmasını gerekli görmektedir. Özellikle bürokraside ehliyete dikkat ederek görevlendirme yapmalı; vezirler, kadılar, komutanlar ve maliyeciler gibi üst düzey yöneticilerin tayininden önce onların ahlâk, meslekî yeterlilik, asalet gibi görevlerinin gereği temel vasıflarının olup olmadığını araştırmalıdır. Göreve geldikten sonra istihbarat birimi aracılığıyla onları denetletmeli, işlerini doğru yaptı̆̆ından ve güvenilir olduklarından emin olmalıdır. ${ }^{57}$

Mâverdî devlet rejiminin din, mal/servet ve kuvvet olmak üzere üç amaçtan biri için kurulacağını söyler. Bu amaçlardan en güçlüsü dinî kuralları tesis etmeye dayalı devlet modelidir. Nitekim ona göre din devletin uzun süre devamını sağlayacak ve devlete bağlılığı pekiştirecek en güçlü amaçtır. Bu devletler daha güçlü ve sağlam temellere dayanıp sürekli itaat üzere olan topluluklardan oluşur. Mâlî amaçlar ve kaygılar üzerine kurulmuş devlet, zenginleşen bir grubun devlet içindeki konumunu kullanarak iktidarı ele geçirmesiyle kurulur ki en zayıf devlet budur. Güce dayalı devletler ise ya halkını baskı ve zulümle idare etmektedir ya da kötü yönetiminden dolayı zayıflamıştır. Baskıcı devlet rejimi zayıfladığında devlet içerisindeki güçlü olan gruplar iktidarı ele geçirme hırsıyla ya da zulmü bitirme amacıyla harekete geçip önde olan birinin etrafında toplanarak devleti ele geçirir. ${ }^{58}$ Mâverdî hükemâdan birine atıfla adâlet ve cesarete dayanan devlet türlerini karşılaştırır. Buna göre devlet başkanı âdil olunca cesarete/şecâata gerek yoktur. Zira cesaret isyan edenlere karşı kullanılan bir güç gösterisidir. Adâlet ise ondan daha üstündür. Çünkü adâlet her güzel şeyin temeli olup insanların iyilik ve huzuru da adâlet ile mümkündür. Bu nedenle adâlet dünya nizamının insanın ve devletin ayakta durabilmesinin şartıdır. ${ }^{59}$

\footnotetext{
55 Mâverdî, Teshîlü'n-nazar, 223-225.

56 Mâverdî, Nasihatü'l-mülûk, trc. Mustafa Sarıbıyı (İstanbul, Ark Yayınları, 2004), 335.

57 Cengiz Kallek, “Mâverdînnin Ahlâkî, İçtimaî, Siyasî Ve İktisadî Görüşleri”, 251-252.

58 Mâverdî, Teshîlün-nazar, 153-156.

59 Mâverdî, Edebü'd-dünya ve'd-din, 154; Teshîlü'n-nazar, 183-184.
} 
Görüldügüü üzere Mâverdî gücün ölçüsüzce kullanılmasına karşı yöneticinin yetkilerini adâlet ilkesiyle sınırlandırmıştır. Adâlet toplumun bireylerinin birbirleriyle ilişkilerini belirleyen bir unsur olmanın yanında Mâverdî̀nin de vurgusuyla yöneticilerin halka yaklaşımının sınırlarını belirleyen dengeleyici ve iktidarın meşruiyetini sağlayıcı önemli bir unsurdur. Bu yaklaşımın kimi siyaset filozofları tarafından üretilen yöneticiye sadakat odaklı yaklaşımlardan daha demokratik bir yaklaşım olduğu görülmektedir. Mesela Machiavelli'nin "Hükümdar"ında hükümdarın halkına karşı tutumunu belirleyen ilke iktidarını sürdürebilme odaklı politikalardır. Hatta akıllı bir hükümdar vatandaşlarını her durumda kendine ve devlete muhtaç kılacak politika üretmelidir. ${ }^{60}$

Mâverdî adâletin bir yönünün insanların birbirlerine karşı ilişkilerinde ortaya çıktığına dikkat çeker. Zira insanların diğerine karşı sosyal yaşam/görgü kurallarına uygun dengeli davranması adâletin sosyal hayattaki bir tezahürüdür. Mâverdî adâleti bu yönüyle kişinin kendisine ve başkasına adâleti olmak üzere ikiye ayırır. Kişinin kendisine karşı adâleti -yukarıda ifade edildiği üzere- kendisini doğru yola yönlendirmesi, çirkin şeylerden uzak tutması ve davranışlarında haddi aşmaması şeklinde sıralanabilir. ${ }^{61}$ Başkalarına karşı adâlet ast, üst ve denk olanlara karşı olmak üzere üçe ayrılır. Yöneticinin halkına veya âmirin emri altındakilere karşı adâletli davranması gibi kendinden daha alt seviyede olanlar hakkında adâlet gözetilirken insanları kolay olan şeylerle sorumlu tutmalı, ağır ve zor sorumluklar yüklememeli, onlara zorbaca davranmaktan kaçınmalı ve yapılan icraatlarda hakka riayet etmelidir. Mâverdî̀ye göre bu ilkelere uyularak adâlet gerçekleştiğinde ülkede karışıklık ve düzensizlik ortadan kalkar, toplum huzurlu olur ve yönetici halkını daha kolay idare eder. ${ }^{62}$ Halkın yöneticilere ve memurların âmirlerine karşı adâleti gibi rütbece kendisinden üstte olan kişilere karşı adâlette ise alttakilerin samimî bağlılığı, üstte olana yardımı, onlara gönülden sevgi ve dostluk kurması suretiyle adâlet sağlanmış olur. Düşünürümüze göre üsttekilere adâlet noktasında bu ilkelere riayet etmeyen kimse zulme maruz kalarak kendisi de zâlimler arasına katılmaya mecbur olur. Halk yöneticiye itaat etmez, sevgi beslemez ve yardım etmezse mülkün temelleri sarsılır, araya fesat ve düşmanlık girer, birlik-beraberlik ve huzur ortadan kalkar; böylelikle ülkedeki düzen bozulur. ${ }^{63}$ Denk olanlara karşı adâlet, görüşme sıklığından dolayı insanların birbirini usandırmaması, aynı şekilde müstağni davranmayı terk etmesi, birbirine yük olacak ve onlara eziyet verecek davranışlardan kaçınmalarıyla olur. Böylelikle insanlar arasındaki güven duygusu artar ve adâlet sağlanmış olur. Bu hususlara dikkat edilmediğinde ise aralarındaki sevgi kısa sürede düşmanlığa dönüşür, tarafların kendileri zarar göreceği gibi başkalarını da zarara uğratırlar. ${ }^{64}$

Mâverdî adâletin birçok halleri bünyesinde barındırdığını Hz. İsa'nın (a.s.) şu sözleriyle açıklar: "Hz. İsa (a.s.) İsrailoğullarına nasihat ederken şöyle demiştir. Ey İsrailoğulları, Cahillerin yanında hikmetli sözler konuşmayın, aksi takdirde zâlim olursunuz.

60 Niccolo Machiavelli, Hükümdar, trc. Mehmet Özay (İstanbul, Şule Yayınları, 1999). 75 vd.

${ }^{61}$ Mâverdî, Edebü'd-dünya ve'd-din, 148.

${ }^{62}$ Mâverdî, Edebü'd-dünya ve'd-din, 154-155.

63 Mâverdî, Edebü'd-dünya ve'd-din, 155.

64 Mâverdî, Edebü'd-dünya ve'd-din, 155-156. 
Hikmet ehlini bulduğunuzda da onlardan hikmeti esirgemeyin yoksa yine zâlim olursunuz. Zâlimlere sevgi göstermeyin, yoksa faziletini kaybedersiniz. Ey İsrailoğulları! İnsan arasındaki işler üç çeşittir. Bunlardan birincisi doğru ve hidayet olduğu bilinir onu yapınız. İkincisi bâtıl ve dalâlet olduğu bilinir, ondan sakınınız. Üçüncüsü hidayet mi dalalet mi olduğu noktasında tereddüte düştüğünüz şüpheli işlerdir ki onları da Allah'a havale ediniz. ${ }^{65}$ Bu şekilde Mâverdî üç grup insanla ilgili hususlarda aşırılıktan kaçınarak orta yolun (itidal) ve böylelikle adâletin sağlanmış olacağını vurgular.

\section{Sonuç ve Değerlendirme}

Ahlâk, siyaset ve diğer bütün alanlar için temel bir ilke olan adâlet, İslam düşünürleri ve filozofları tarafından pek çok yönüyle incelenmiştir. Mâverdî her ne kadar felsefî geleneğin önemli simalarında olduğu gibi bariz bir şekilde metafizikten ahlâk ve siyasete uzanan teorik bir adâlet yaklaşımı ortaya koymamış olsa da fikirlerinin siyasete ilişkin pratik yönünün oldukça güçlü olduğu ve bu nedenle uygulamalı bir adâlet teorisi ortaya koyduğunu söylemek mümkündür. Zira o, siyaset ve hukuk başta olmak üzere pek çok alanda kaleme aldı̆̆ı eserlerle yaşadığı çağı iyi yorumlayıp engin devlet tecrübesiyle temâyüz etmiş önemli bir şahsiyettir.

Mâverdî düşüncesinde ahlâkî bir erdem olarak adâlet hem hak ve hukuka uygun davranmak hem de bireyin bütün davranışlarını düzenleyen ve dengeleyen ana erdem görevini yapar. Siyasette ise devlet yönetiminin, kamuya ait işlerin en uygun şekliyle tesisini sağlayan devletin üstüne bina edilmesi gereken temel bir ilkedir. Mâverdî devletin her bir kurumunda ehliyet ve liyâkati önemseyip toplumun her kesimini kuşatan bir siyaset anlayışı üretmiş, adâletin önemsenmediği yönetimlerde yönetimin ve toplumun karşılaşacağı sıkıntıları da açıklamıştır.

Adâletli olma ilkesini bireyin iç dünyasından başlayarak kanonik bir şekilde kamu yönetimine kadar genişleten Mâverdî yönetimin/iktidarın icraatlarının meşrûiyetini sağlayan ve icraatlarını düzene sokan bir araç olarak da yine adaleti görür. Zira o, devlet yönetimini adâlete riayet eden ehil insanlardan oluşan bir mekanizma olarak görür. İcra edilen her bir kamu görevinde de ilk olarak adâlet şartını arar. Yine devletin vatandaşından vergi almada haksızlık yapmaması, davaların görülmesinde hakkaniyetli olması gibi pek çok konuda adâleti temel bir ilke olarak belirlemiştir. Devlet yönetimini adâlet temeli üzerine kuran Mâverdî adâleti yöneticinin keyfî davranışlarını sınırlandıran değerli bir esas olarak görmüş, devlet başkanının ve yönetiminin ilke edinmesi gereken en üst mekanizma olarak kabul etmiş ve başkanın mutlak otoritesini vurgulamakla birlikte onun da otoritesini sınırlayan erdemin adâlet olduğunu belirtmiştir. Netice itibariyle kaleme aldığı eserlerin her yerine adâlet vurgusunun nakşedilmiş olduğunu gördüğümüz Mâverdî’nin metinlerinde adâletin bireysel hayattan devlet idaresine kadar her alanda anahtar niteliğinde değişmeyen temel bir erdem olduğunu anlamamız mümkündür.

65 Mâverdî, Edebü'd-dünya ve'd-din, 156-157; Vecdi Akyüz, "Mâverdî ve Hukuk”, 5/1193. 
Etik Beyan / Ethical Statement

Yazar / Author
Bu çalıșmanın hazırlanma sürecinde bilimsel ve etik ilkelere uyulduğu ve yararlanılan tüm çalışmaların kaynakçada belirtildiği beyan olunur/It is declared that scientific and ethical principles have been followed while carrying out and writing this study and that all the sources used have been properly cited. Fatih Aydin

\section{Kaynakça}

Akyüz, Vecdi. “Mâverdî ve Hukuk”. Doğudan Batıya Düşüncenin Serüveni. 5/1175-1196. İstanbul: İnsan Yayınları, 2015.

Aristotle. Magna Moralia (The Works of Aristotle IX). Londra: Oxford University Press, 1949. ed.W. D. Ross. Barca, İbrahim. İslam Kurumları Tarihi Açısından Ebü'l-Hasan Ali b. Muhammed b. el-Habib el-Mâverdî elBasrînin Kavânînül-vizâre ve siyasetü'l-mülk" Adlı Eseri. Şanlıurfa: Harran Üniversitesi Sosyal Bilimler Enstitüsü, Yüksek Lisans Tezi, 2012.

Birsin, Mehmet. Mâverdînin Devlet Anlayışı. Ankara: Ankara Üniversitesi Sosyal Bilimler Enstitüsü Doktora Tezi, 2004.

Çağrıc1, Mustafa. "Adâlet”. Türkiye Diyanet Vakfi İslâm Ansiklopedisi. 1/341-343. İstanbul: Türkiye Diyanet Vakfi Yayınları, 1988.

Çağrıc1, Mustafa. "Mâverdî de Siyaset Ahlâkı". İslamiyât 6/1 (2003), 71-92.

Bağdâdî, Ahmet Mübarek. "Mâverdî̀nin Siyâsî Düşüncesinde İnsan ve Toplum”. Dicle Üniversitesi İlahiyat Fakültesi Dergisi. trc: Mustafa Sarıbıyık. 5/2 (2003), 77-99.

Erkal, Mehmet. “Ahkâmü’s-sultaniyye”. Türkiye Diyanet Vakfi İslâm Ansiklopedisi. 1/555-556. İstanbul: Türkiye Diyanet Vakfı Yayınları, 1988.

Evkuran, Mehmet. “Mâverdî̀nin Düşünce Dünyası”. Doğudan Batıya Düşüncenin Serüveni. 5/11971222. İstanbul: İnsan Yayınları, 2015.

Haddurî, Mâcid. İslâmda Adâlet Kavramı. trc. Selahattin Ayaz. İstanbul: Yöneliş Yayınları, 1991.

Hamidullah, Muhammed. İslâm'da Devlet İdâresi. trc. Hamdi Aktaş. İstanbul: Beyan Yay, 2007.

İbn Manzûr. Lisânu'l-arab. Beyrut: Daru's-Sadr, 1990.

İnalcık, Halil. "The Origin and Definition of the Circle of Justice (Dâire-i Adâlet)". Selçuklu'dan Osmanliya Bilim Kültür ve Sanat: Prof. Dr. Mikail Bayram'a Armağan. ed. Mustafa Demirci. Konya, Kömen Yayınları, 2003.

Kallek, Cengiz. "Mâverdînin Ahlâkî, İçtimâ̂, Siyasî ve İktisadî Görüşleri”. Divan Disiplinlerarası Çalı̧smalar Dergisi. 14 (2004), 219-265.

Kaplan, Yunus. “Osmanlı'da Adâlet Mefhumunun Kökenleri”. Journal of Islamic Research. 31/1 (2020), 143-163.

Karaca, Osman. Mâverdînin Ahlâk görüşü. Van: Yüzüncü Yıl Üniversitesi Sosyal Bilimler Enstitüsü, Yüksek Lisans Tezi, 2008.

Karagözoğlu, Hümeyra. “Ahlâk Düşüncesinde Siyaseti Aramak: İbn Miskeveyh'te “Adâlet” Kavramının Siyâsî Yansımaları”. Divan Disiplinlerarası Çalışmalar Dergisi 14/27 (2009), 93-118.

Machiavelli, Niccolo. Hükümdar. trc. Mehmet Özay. İstanbul, Şule Yayınları, 1999.

Mâverdî, Ebü'l-Hasen Alî b. Muhammed b. Habîb Basrî. A'lâmü'n-nübüvve. nşr. Muhammed elMu'tasım-Billâh el-Bağdâdî. Beyrut: 1407/1987).

Mâverdî, Ebü'l-Hasen Alî b. Muhammed b. Habîb Basrî. Ahkâmüs-sultaniyye ve'l-vilâyâtü'd-diniyye. thk. Ahmed Mübarek Bağdâdî. Kuveyt: Dâru İbn Kuteybe, 1989. 
Mâverdî, Ebü'l-Hasen Alî b. Muhammed b. Habîb Basrî. Dürerüs'sülûk fî siyasetil'-mülûk. trc. Abdüsselam Arı. İstanbul: Türkiye Yazma Eserler Kurumu, 2019.

Mâverdî, Ebü'l-Hasen Alî b. Muhammed b. Habîb Basrî. Nasihâtü'l-müluk. trc. Mustafa Sarıbıyık. İstanbul: Ark Yayınları, 2004.

Mâverdî, Ebü'l-Hasen Alî b. Muhammed b. Habîb Basrî. Teshilü'n-nazar ve ta'cilü'z-zafer fi ahlâki'l-melikve siyasetil-mülk. Beyrut: Dâru'n-nahdati'l-Arabiyye, 1981.

Okumuş, Ejder. “Osmanlılar'da Siyasal Bir Kurum Olarak Adâlet Dairesi”. Sosyal Bilimler Araștırma Dergisi 3/5 (2005), 45-51.

Sarıbıyık, Mustafa. Mâverdînin Nasihatü'l-mülûk'u ve Siyasî Görüşleri. Konya: Selçuk Üniversitesi Sosyal Bilimler Enstitüsü, Doktora Tezi, 1996. 